\title{
The "War" Against Covid-19: State of Exception, State of Siege, or (Constitutional) Emergency Powers?: The Italian Case in Comparative Perspective
}

\author{
Claudio Corradetti ${ }^{1, *}$ and Oreste Pollicino ${ }^{2,3}$ \\ ${ }^{1}$ Tor Vergata University, Rome, Italy, ${ }^{2}$ Bocconi University, Milan, Italy and ${ }^{3}$ Executive Board Member, EU Agency for \\ Fundamental Rights, Vienna, Austria \\ *Corresponding author: Claudio.Corradetti@uniroma2.it
}

(Received 07 March 2021; accepted 19 June 2021)

\begin{abstract}
Is the Covid-19 pandemic changing the constitutional-power structures of our democracies? Is this centennial public health emergency irreversibly constraining our liberties? The paper examines recent statemeasures of containment during the initial phase of spread of the Covid-19 crisis. It compares primarily the Italian scenario with the Chinese and the American one. It asks whether the measures adopted particularly in the Italian case (known as DPCMs) amount to a state of exception or to a use of emergency powers. Cognizant of the authoritarian risks in severed enjoyments of constitutional rights, the authors conclude that this is not what occurred in the case of solid democracies. At the level of governmental analysis, the "decree" strategy of the Italian DPCMs allude to paternalistic forms of power-exercise that empty the self-determining prerogative of the parliament.
\end{abstract}

Keywords: State of exception; Covid-19; Emergency powers

\section{A. Introduction}

The current coronavirus pandemic has suddenly stopped the frenzy of our day-to-day life and productive activities. Democratic governments have marked phases of suspension of normality. Media and public debates have often deployed the language of warfare by referring to a "war" against Covid19 , where the virus is fought back, its power contained, and where medics and paramedics are "frontline soldiers." Following Lakoff's analysis, one could speak of a cognitive metaphor of war as the source domain structuring the conceptually ill-defined domain of the virus, the target domain. ${ }^{1}$

This same conceptual frame has been extended also to the structuring of the cognitive domain of our perceptions, to the way in which political power has readjusted itself. Reference to notions

The Article is the result of a joint effort. However, Introduction, Section II, the second half of Section III, and the Conclusion have been drafted by Claudio Corradetti, and the remaining part by Oreste Pollicino. The authors thank Giovanni De Gregorio for his editorial support.

Claudio Corradetti has a background in philosophy and public international law. He has published extensively on the theory of human rights, transitional justice, Kant and modern political thought. Before returning to Italy, he has been a lecturer at the University of Oslo, PluriCourts. In 2020 he was a Fulbright scholar at Columbia University, NY.

Oreste Pollicino has extensively focused his research on Constitutional law and Internet law. He is the Director of the LLM in Law of Internet Technologies at Bocconi University. He is also a member of the board of the European Fundamental Rights Agency.

${ }^{1}$ On the role of cognitive metaphors in the study of the language-mind issue, see the seminal works by G. LAKOFF \& M. Johnson, Metaphors We Live By (1980); G. Lakoff, Women, Fire and Dangerous Things (1987).

(C) The Author(s) 2021. Published by Cambridge University Press on behalf of the German Law Journal. This is an Open Access article, distributed under the terms of the Creative Commons Attribution licence (http://creativecommons.org/licenses/by/4.0/), which permits unrestricted re-use, distribution, and reproduction in any medium, provided the original work is properly cited. 
of "emergency powers," "state of exception," or "state of siege" indicates the self-protecting ways in which power confronts this new threat. In Italy the head of government Giuseppe Conte issued what appeared to critics to be periodical "edicts" known as DPCMs-Decrees of the Prime Minister-expression of politics. In England, Boris Johnson, after a rash first call for improbable flock immunity, adopted the Coronavirus Act 2020. Donald Trump finally drew the attention of the 1950 National Defense Act and all federal states declared a state of emergency for the first time in U.S. history. It was an unusual exercise of power and political communication justified by the gravity of the moment but with potentially dangerous implications.

In fact, what would happen if this emergency were destined to repeat itself and become the current form of exercise of public power? What should we expect from governments if they operate under the risk of constant contamination? Certainly, the hypothesis of a protracted management of pandemic exceptionalism has already entered the political mindset of governments. The widespread implementation of lockdowns and restrictions on personal freedoms has already laid the foundations for new emergency management with respect to population policies. However, distinctions must be made to understand whether the current scenario is configured as an exercise of exceptional power, or if it is more simply the adoption of time-limited measures that are part of an emergency management within a democratic constitutional framework.

\section{B. What is the State of Exception?}

Central to theoretical-political reflection, the state of exception has traversed different contexts of theorization that lend themselves, in our opinion, and its trans-historical extensibility in the absence of a precise contextualization.

The state of exception is a concept first theorized by Carl Schmitt in two of his writings: Dictatorship and Political Theology ${ }^{2}$ and then reinterpreted by Giorgio Agamben in Homo Sacer and State of Exception ${ }^{3}$ in terms of its "normalization" in today's democratic exercise of power. ${ }^{4}$

According to Agamben, the current case of the coronavirus-induced crisis would only be a confirmation of the device of exception as a normalized paradigm. Therefore, the decree-law approved by the Italian government for reasons of hygiene and public safety would result in a real militarization "of the municipalities and areas in which at least one person is positive...."

For the Schmitt of 1933, the relevant point was to the long descending parable of the Weimar Republic and, in particular, to its constitutional Article $48^{6}$ which paved the way for the Nazi dictatorship through Hitler's proclamation of the Reichstag Fire Decree. Article 48 established, in the event of a threat to public safety, the seven constitutional articles concerning suspended individual and association freedoms. As is well known, it was the newly elected chancellor Adolf Hitler who decided on the suspension. These articles would no longer be rehabilitated by the regime, but the regime would not revoke or abolish the Weimar Constitution. It is therefore this concrete possibility of establishing the exception that indicates the type of historical and legal state that Schmitt has in mind when he asks to overcome the post-1933 constitutional impasse of Weimar by requesting the proclamation of a new Constitution for the Reich.

The difference between the state of exception and the state of emergency is of fundamental importance for the integration not only of the Schmittian theory of the exceptional nature of power-and of the revolutionary popular power that arrives and selfdetermines in the Führer -but also for the difference-on the historical-juridical level- of the figures in which the

\footnotetext{
${ }^{2}$ C. Schmitt, Dictatorship (M. Hoelzl \& G. Ward trans., 2021); C. SChmitt, Political Theology: Four Chapters on THE CONCEPT OF Sovereignty (G. Schwab trans., 2005).

${ }^{3}$ G. Agamben, Homo Sacer: Sovereign Power and Bare Life (1998).

${ }^{4}$ G. Agamben, State of Exception, (2003).

${ }^{5} \mathrm{G}$. Agamben, L'invenzione di Un'Epidemia, https://www.quodlibet.it/giorgio-agamben-l-invenzione-di-un-epidemia (translation by author).

${ }^{6}$ The Constitution of the German Empire of August 11, 1919 (Weimar Constitution).
} 
exceptional nature of power differs from the states of emergency. Schmitt distinguishes these two aspects in the Appendix section of the text Dictatorship where he separates the Constitutional Emergency Law (Staatsnotrecht) from the proper state of emergency. ${ }^{7}$ Constitutional Emergency laws can be contested by any governing body to protect the constitutional order. Whereas the use of emergency powers might proceed above the law, Constitutional Emergency laws are compatible only with a constitutional emergency use of power.

In this second case, there is state of exception in the proper sense, one which Schmitt identifies with the figure of the sovereign decision. This explains why Schmitt in Political Theology affirms that the sovereign is "who decides on the exception" (Ausnahmezustand) ${ }^{8}$ but only in so far as this concept-exception - is "associated with a borderline case (Grenzbegriff) and not with routine." 9

What this means is clarified a little further when Schmitt affirms that such definition does not point "merely to a construct applied to any emergency decree or state of siege" (nicht irgendeine Notverordnung oder jeder Belagerungszustand). ${ }^{10}$

So, we could conclude, that the invocation of Article 48 of the Weimar Constitution for Schmitt does not always refer to a juridical exceptionality but often concerns a use of the power of the "emergency decrees" (Notverordnungen) as they were actually used before 1933 in connection with the economic difficulties of Germany. In fact, the use of Article 48 initially fell within a legitimate exercise of constitutional powers because its use was conditional on the consent of the Reichstag. Only when Article 48 was challenged as an instrument of unconditional abrogation of freedoms, it passed to a condition of full exceptionality. That is, to what could be defined as a condition of (re)-constituent state of exception. It is in this perspective therefore that Schmitt's call for the formulation of a new constitution for the Third Reich must be understood.

This passage can only take place extra legem. Unlike emergency ordinances or states of siege, in fact, the decision on the state of exception properly understood constitutes a "decision in an eminent sense" (im eminenten Sinne)."11

The point that interests us now is the following: Can we believe that the emergency posed by the pandemic of the coronavirus is of absolute exceptionality, such that the decision to adopt certain administrative measures is configured as an instance of normalized exception?

The latter seems hardly to be the case, although there are elements in the current context that illustrate the idea of exceptionality as a suspension of the law. Consider, for example, the way in which today's economic governance of the European Union is defined largely through international capitals and supra-European bodies such as the International Monetary Fund or the World Bank. It is true, however, that the emergency legal act arises as an internal derivative measure to an already established legal power-and therefore in a non-foundational way with respect to power as absolute sovereignty exception.

That today's situation falls into this second case is also inferred from the fact that only with regard to the Constitutional Emergency Law (Staatsnotrecht) — but not in the state of exception — can emergency exit-phases be planned while remaining within the scope of a constitutional exercise of power.

\footnotetext{
${ }^{7}$ See." C. SchmitT, Dictatorship 201 (2014) ("Constitutional emergency law is based on the fact that, in an extreme and unpredicted situation, any organ of the state that has the power to act leads the way outside or against constitutional provisions, in order to save the existence of the state and to do what the concrete situation requires. Such a law, which most states' governments arguably had to resort to during the war, is frequently justified through the argument that there should be a 'lacuna' for it in the constitution ....")

${ }^{8}$ C. Schmitt, Political Theology 5 (2005).

${ }^{9} I d$. Also see C. SCHмitT, Dictatorship (2014), in which Schmitt considers that whereas the institute of dictatorship in Rome was delegated and limited in time, namely, as a power exclusively directed to the extra-juridical defence of the Republic, it was with the development of the commissarial dictatorship, first, and then with the French revolutionary power that sovereignty merged with democracy. The power of sovereign people, at that point, did not direct itself anymore to the protection of a constitutional order already given, but placed itself as a creator of a new juridical order. The constituent people were therefore by their very function: extra legem.

${ }^{10}$ SchmiTt, Supra note 7 , at 5.

${ }^{11} I d$. at 6.
} 
To provide an example, Article 16 of the Italian Constitution states that circulation is free except for established limitations "for reasons of health and security" (per motivi di sanità o di sicurezza), ${ }^{12}$ and no limitation may arise "from political reasons" (da ragioni politiche). ${ }^{13}$ This is a conscious formulation of the events of the 1900s and for this reason much more restrictive than that of Article 48 of Weimar where the President could propose to "suspend for a while, in whole or in part, the fundamental rights provided for in articles 114, 115, 117, 118, 123, 124, and 153," ${ }^{14}$ as namely, the articles concerning the various rights of freedom of expression, association, press, as well as private property. The constitutional emergency use of power, however, does not intend to replace a condition or a state of normality for the constitutionality of power. The justified emergency use of power is aimed primarily at an internal enemy, such as defeating the virus in view of protecting the population. The ad hoc limitation of some rights is justified only in view of measures to contain the epidemiological risk, without the possibility of a withdrawal of parliamentary powers - as in the case of the state of exception. The apparent overlap between emergency use of power and state of exception, however, derives from the fact that emergency power paradoxically associates the efficiency of decision-making timeliness with the annihilation of political and social life. Politics cancel political life itself. The awareness of a radical transformation of the current use of power stands as something always exposed to emergency use.

The downside of the story, though, is that there are some potentially undemocratic implications embedded in the process. To mention one, an "efficientist" turn of the democratic power-form, if not limited in time and occurrence, would tend to align liberal democracies' practices with the modus operandi typical of illiberal ideological regimes. This is a slippery-slope threat. Indeed, the reactive ability of illiberal but efficient countries may inevitably reverse the competitive relationship of international accreditation. Pragmatic efficiency would erode the limitations imposed by rights in the name of use of emergency measures. In fact, ideological-authoritarian states have an advantage in the use of emergency powers compared to democratic states and even more so than states without or almost no health welfare. The collective ideological assumption on which authoritarian states are based allows them to act quickly. In this sense, the ability with which China has been able to cope with the epidemiological crisis of the coronavirus will enter, at least in part, the political horizon of democratic countries defining new prerogatives of power. But once the emergency use of power is accepted by the electorate as inherent in the democratic exercise, the private confinement of associated life will become an increasingly available option also for the measures of democratic politics. The use of IT systems will facilitate this process. Not only will political dissent be expressed mostly in virtual language, the squares may be places of potential contagion, but the political agenda will take into account a risk factor always lurking.

These are only speculative possibilities. However, it would be hard to think that these options alone would suffice to destroy the liberal ethos of western democracies.

The coronavirus has undoubtedly marked a change in the exercise of public powers, but this is not the viaticum of a new legal order. To understand the shifts and restructurings of contemporary powers we must look elsewhere. The current pandemic of the coronavirus informs us only of a more modest internal settlement of powers, that is, of their adaptation to the needs of current public health emergencies. It would be fatal to miss the target now at this still undefined phase of the new dangers for liberal democracies.

Certainly, there remains an asymmetry in the use of emergency powers between "liberal" and "authoritarian" democracies. It is indeed the case that whereas in countries in which parliamentary powers had been eroded by strong executives - such as the case of Hungary in Europe-the exceptional measures necessary to contrast Covid-19 have been instrumentally used to limit further parliamentary prerogatives, and in the case of solid liberal democracies, this has found countervailing institutional mitigation. The two cases must therefore be kept separate in so far as the democratic restrictive effects of the pandemic - as a cause-is concerned.

\footnotetext{
${ }^{12}$ Art. 16 Costituzione [Cost.] (It.).

${ }^{13} I d$.

${ }^{14}$ Art. 16 Weimar Const.
} 
Let us now examine some comparative legal outcomes prompted by the power shifts of the corona pandemic. This survey will substantiate with empirical data the considerations developed so far on the constitutional acceptability of most emergency measures.

\section{Is Covid-19 Prompting States of Exception Reactions?}

The specificity of the Italian regulatory emergency approach to isolation in the pandemic can be seen in contrast to that of the US on the one hand and China on the other.

The U.S. response began on January 31 when the Department of Health and Human Services (HHS) proclaimed a Public Health Emergency. According to the National Disaster Medical System Federal Partners Memorandum of Agreement, a public health emergency is "an emergency need for health care [medical] services to respond to a disaster, significant outbreak of an infectious disease, bioterrorist attack or other significant or catastrophic event." This type of emergency "may include but is not limited to, public health emergencies declared by the Secretary of HHS under 42 U.S.C. 247d, or a declaration of a major disaster or emergency under the Robert T. Stafford Disaster Relief and Emergency Act (Stafford Act), 42 U.S.C. 5121-5206)."15

On February 4, the Secretary of the Department of Health and Human Services enacted the declaration of Public Readiness and Emergency Preparedness (PREP) Act. The PREP Act "provides immunity from liability (except for willful misconduct) for claims of loss caused, arising out of, relating to, or resulting from administration or use of countermeasures to diseases, threats and conditions determined by the Secretary to constitute a present, or credible risk of a future public health emergency to entities and individuals involved in the development, manufacture, testing, distribution, administration, and use of such countermeasures."16

Furthermore, on March 13, President Trump invoked Article 501(b) of the Robert T. Stafford Disaster Relief and Emergency Assistance Act (known as the Stafford Act) that "constitutes the statutory authority for most Federal disaster response activities especially as they pertain to U.S. Federal Emergency Management Agency (FEMA and FEMA programs)." ${ }^{\prime 7}$ Effectively identifying the pandemic as a "situation ... of such severity and magnitude that effective response is beyond the capabilities of the State and the affected local governments and that Federal assistance is necessary," setting up Emergency Assistance Programs and empowering state Governors to "take appropriate action under State law and direct execution of the State's emergency plan."18 Finally, on the same day, President Trump also declared a National Emergency Concerning the Novel Coronavirus Disease (Covid-19) Outbreak (Proclamation 9994) ${ }^{19}$ according to which he would give the states and territories access to up to fifty billion dollars in federal funds to fight the coronavirus pandemic. This includes the ability to waive laws to enable telehealth, a system of "distribution of health-related services and information via electronic information and telecommunication technologies" 20 that "allows long-distance patient and clinician contact, care, advice, reminders, education, intervention, monitoring, and remote admissions." ${ }^{1}$

\footnotetext{
${ }^{15}$ Nat'l Disaster Med. Sys., Memorandum of Agreement Among the Departments of Homeland Security, Health and Human Services, Veterans Affairs, and Defense, https://web.archive.org/web/20090106082632/http:// emilms.fema.gov/IS1900_NDMS/assets/NDMS_Partners_MOA_with_sig.pdf (2005).

${ }^{16}$ U.S. Dep’t of Health \& Human Services, Public Readiness and Emergency Preparedness (PREP) Act of 2005, https://www.phe.gov/Preparedness/legal/prepact/Pages/default.aspx (2005).

${ }^{17}$ Robert T. Stafford Disaster Relief and Emergency Assistance Act of 2019, 42 U.S.C. $\$ \$ 5121-95$, https://www.fema.gov/ sites/default/files/2020-03/stafford-act_2019.pdf.

${ }^{18} I d$.

${ }^{19}$ Proclamation No. 9994, 85 Fed. Reg. 15337 (Mar. 13, 2020).

${ }^{20}$ Health Res. \& Serv. Admin., Telehealth Programs, https://www.hrsa.gov/rural-health/telehealth/index.html (2021).

${ }^{21}$ Donald K. Shaw, Overview of Telehealth and Its Application to Cardiopulmonary Physical Therapy, 20(2) Cardiopulmonary Physical Therapy J. 13-18 (2009), https://www.ncbi.nlm.nih.gov/pmc/articles/PMC2845264/.
} 
In parallel, multiple state and local emergency declarations occurred in March. In line with federal law, these declarations introduced emergency powers to alter procurement contracts, introduce emergency plans, set up interstate coordination, adopt price controls and payment waivers, as well as implement specific surveillance testing, screening, treatment techniques, and restrict travel.

All in all, disciplinary measures introduced in the context of the state of emergency were much more lenient than in many countries. Emergency measures related to citizen isolation were rarely obligatory and rarely directly enforced by authorities. They were left to adoption and self-enforcement by citizens. In general, these measures were left to each state to specifically define and introduce, and included quarantine, curfew, and domestic travel restrictions, while the federal government stipulated foreign travel restrictions. At the same time, the emergency response by the authorities was much more focused on the distribution of vast financial relief for businesses and citizens.

However, even these isolation-based measures have often been met with resistance and push back. Since April, over two dozen state officials have resigned, retired, or been fired.

In April and May 2020, the Tri-Country (CO) Health Department was vandalized on multiple occasions. On May 9, the residence of Ohio's state health director was picketed. On June 11, armed protestors surrounded the property, leading to her resignations that same day. On June 8, the health officer of Orange County (CA) resigned amid social media threats; on August 4, the NYC Health Commissioner resigned amid controversy with the mayor and finally on August 9, California Department of Public Health Director resigned following surveillance concerns. Furthermore, some of the emergency measures have already created legal controversy. Namely, on July 7, the Freedom Foundation filed a lawsuit challenging the constitutionality of the state of Washington's mask mandate. On July 27, it sued the state of Oregon over its mask mandate, while State of Georgia Governor Kemp pursued a case against the City of Atlanta regarding its mask requirement.

Turning to the Chinese experience of dealing with the pandemic, we should first note that part of its specificity stems from the fact that it was the first jurisdiction to confront it. The legal framework that set the stage for this response was developed during the 2003 SARS crisis. It included: The Emergency Response Law, "enacted for the purpose of preventing and reducing the occurrence of emergencies, controlling, mitigating and eliminating the serious social harm caused by emergencies, regulating the activities in response to emergencies, protecting the lives and property of the people, and maintaining national security, public security, environmental safety and public order," 22 the Law on Prevention of Infectious Diseases and its Ministry of Health Implementation Measures, the National Public Health Emergency Plan, and the State Council Health Emergency Regulation. As one commentator explains, these four laws "establish a four-tier response system for public health emergencies, allow measures including lockdowns and quarantines (which limit personal liberty, safeguarded by Article 37 of the PRC Constitution) and provide for the declaration of a national state of emergency." ${ }^{23}$ On the basis of this framework, on January 25, 2020, a high-level public health emergency was declared in thirty-one provinces and autonomous regions, "in accordance with the National Contingency Plan." Importantly, no national emergency was declared.

It is noteworthy that on January 23, 2020, after the Class 2 and Class 1 Response to Public Health Emergency declared by the local Hubei authorities on January 22 and 23, the central government took over the governance of the process and imposed a lockdown in Wuhan and other cities in the Hubei province in an effort to quarantine the outbreak of coronavirus disease 2019

\footnotetext{
${ }^{22}$ Emergency Response Law of the People's Republic of China (promulgated by the Standing Comm. Nat'l People's Cong., Aug. 30, 2007) http://www.china.org.cn/china/LegislationsForm2001-2010/2011-02/11/content_21899265.htm (China).

${ }^{23}$ Eva Pils, China's Response to the Coronavirus Pandemic: Fighting Two Enemies, Verfassungsblog May 25, 2020, https:// verfassungsblog.de/chinas-response-to-the-coronavirus-pandemic-fighting-two-enemies/.
} 
(Covid-19). This was the first known instance in modern history of locking a major city down of as many as eleven million people. In the process that followed, at least 56 million Hubei residents were isolated. All public places except hospitals, supermarkets, farmers' markets, gas stations, and drug stores were closed. ${ }^{24}$ Starting from February 1, the Hubei city of Huanggang introduced a curfew which allows only one member of a local family to shop on the streets every two days, making it the first city to restrict its people from going outdoors-which stands in stark contrast to the voluntary quarantine and curfew observed in the U.S. ${ }^{25}$ Furthermore, in all of these cases, in contrast to the U.S. approach, it was the central government that retained the power to initiate and authorize provincial governments in responding to the pandemic. Finally, the ability to contest the government's policy has been limited throughout the process. According to the example mentioned in the literature, in contrast to the Law on Prevention of Infectious Diseases according to whom those whose "lawful rights" have been violated "may apply for administrative reconsideration or initiate legal proceedings according to law," the Emergency Response Law stipulates that "where there are more than one option available for choice, the one that is advantageous to protection of the rights and interests of citizens, legal persons and other organizations to the maximum extent shall be chosen." The difference with the U.S. case is best conceptualized in the analysis of one of the commentators:

This is a weak constraint at best because there is no clear prohibition of rights violations in cases where no rights-protecting option is 'available.' It to some extent reflects the-from a rule of law perspective, flawed-logic of Article 51, PRC Constitution, which stipulates that in exercising their constitutional rights, citizens must not 'infringe upon the interests of the State, of society, or of the collective, or upon the lawful freedoms and rights of other citizens. ${ }^{26}$

Having this comparative context in mind we can now turn to the Italian case. ${ }^{27}$ In terms of legal instruments to deal with emergencies outside the "state of war," Article 77 of the Italian Constitution foresees a standard measure, law decrees, that have force of law, adopted by the Government in case of extraordinary necessity and urgency. Those are issued by the President of the Republic and are immediately introduced to Parliament to be transposed into law-which must happen within 60 days, or the decree loses effect from the beginning. On the basis of a law decree, or other primary law sources, the Government can adopt the decrees of the President of the Council of ministers (DPCM): An administrative act that is issued by a Minister within the competences of its department.

Italian regulatory response to the pandemic started with a resolution of the Councils of Ministers of January 31, 2020 that declared the state of emergency based on Article 24 of the Legislative Decree n.1 of January 2, 2018 (Civil Protection Code). It is important to note that this resolution does not provide for any form of parliamentary validation. Its main effect is the attribution to the head of Civil Protection of extraordinary powers for crisis management, to be exercised by means of ordinances. In this sense, it is important to specify that this declaration does not constitute the legal basis of the Decree of the President of the Council of Ministers (DPCM) adopted later.

The second decree stipulated three zones (red, orange and yellow) going from the red one where the whole population is in quarantine to a yellow one where social and sports events are suspended and schools, theatres, clubs, and cinemas are closed, and the rest of the national

\footnotetext{
${ }^{24}$ Nicola Smith, China Locks Down 14 cities as Wuhan Coronavirus Spreads, The TelegraPH Jan. 24, 2020, https://www. telegraph.co.uk/news/2020/01/24/china-locks-eight-cities-pledges-new-hospital-within-six-days/.

${ }^{25}$ Yang Danxu, China's Confirmed and Dead Cases Hit a New High in a Single Day, Huanggang May Become "the Second Wuhan," ZАовао FeB. 2, 2020, https://www.zaobao.com/special/report/politic/cnpol/story20200202-1025551.

${ }^{26}$ Pils, supra note 22.

${ }^{27}$ This analysis closely follows the report of Elisa Gibellino on the Italian regulatory approach to the pandemic that will appear on-line as part of the Global Comparative Covid project that one of the authors supervises.
} 
territory, where safety and prevention measures are advertised in public places and special sanitizations are performed on means of public transport. Furthermore, the Decree did not implement specific measures, but limited itself to authorizing the Government, through the President of the Council, to do so, thus constituting an act of government "self-delegation." This move would violate at least two of Rossiter's identified constraints for legitimate adoption of emergency legislation in democracies, as the idea that 1) those who establish the emergency cannot be the same as those who decide upon it, and 2) the terms of the emergency's cessation must be established in advance. $^{28}$

The discussion concerning limited rights during the lockdown in Italy is still a rather sensitive one. To prevent the virus from circulating freely, the government, on the advice of the ministry of health, has decided to stop all unnecessary activities, such as the closure of shops that do not sell basic necessities or pharmacies - which could be a violation of the right to freedom of economic initiative under Article 46 of the Constitution - the closing of all cultural demonstrations and of schools. However, what struck the hardest and raised the most perplexities was the ban on movement-violations of the right to free movement under Article 16 of the Constitution-having been enacted through the DPCM, they are fundamentally administrative acts or second-rank sources that could in no way limit the rights of individuals. Furthermore, the role of the regions that was supposed to be substantial in deciding the specific approach ended up being a dead letter. With the issuance of the law decree of March 19, the regions were expected to participate in the procedure aimed at identifying the measures to contain the infection. The way in which the regions should participate takes the role of the "compulsory opinion" which however emptied the meaning of the participation of the regions.

First, during the lockdown, there was an institutional conflict between the regions and the government in the management of the crisis. Initially, this was due to the ambiguous formulation of the Law Decree n. 6 of February 23, 2020, entitled "Urgent measures for the containment and management of the epidemiological emergency from Covid-19." Article 2 of the same Law Decree, in fact, has attributed the power to take further measures than those specifically indicated in Article $1 .^{29}$ The generality of the provision has favored the proliferation of measures issued by the Presidents of the Regions in the form of contingent and urgent ordinances which, in many cases, have ordered measures restricting the freedoms of citizens in contrast with, and even more stringent than, those of the state. To remedy the situation of uncertainty and the growing spread of the epidemic, the Government intervened with Law Decree n. 19 of March 25, 2020. This time, the body of the text of Law Decree n. 19, which aims at predetermining the specific areas of competence of the Regions and the type of restrictions that may be placed on the freedoms and fundamental rights resulting from the list of Article 1, para. 2, highlights the concrete intention to rationalize and clarify relations between the State and the Regions.

Second, the Law Decree n. 19 foresees that the DPCM, which will contain the concrete measures and which from time to time will express not only the restrictive measures but also the choices regarding the return to normal, will moderate the gradual reopening of economic activities. These activities are only communicated to the chambers after publication, and every 15 days the Prime Minister or a delegated Minister reports to the Chambers in a specific debate. From the wording of the decree, a relationship between Parliament and Government is created completely ex-novo, which, in reality, is specifically governed by the Constitution. The role of Parliament and the Senate was found to be rather marginal and not very incisive during the real pandemic. After

\footnotetext{
${ }^{28}$ Cf. C.L. Rossiter, Constitutional Dictatorship: Crisis Government in the Modern Democracies 298 (1948).

${ }^{29}$ U.N. Environment Programme, "Decree-Law 23 February 2020, n. 6 Urgent Measures regarding containment and emergency management of the epidemiological emergency from COVID-19" (Fe". 23, 2020), https://leap.unep.org/countries/it/ national-legislation/decree-law-23-february-2020-n-6-urgent-measures-regarding.
} 
the end of the lockdown, the Parliament, by resuming its normal activities, converted the decrees issued by the government into law.

\section{Considering the Italian Regulatory Approach in the Context of the U.S. and Chinese One in Relation to the State of Emergency and Exception}

If the U.S. case presents the end at which measures are adopted by regional authority while the central authority takes the supportive role and the Chinese case presents the opposite end, the Italian case appears more similar to the Chinese one. However, this comparison is contestable. In such sense this type of emergency does not create an exception from the existing process of legitimization of adopted rules. Besides, it is indeed doubtful that the potential contestation of regulatory measures that are still embryonal will reach the levels that we can observe in the U.S. case on pressuring the political systems by enforcing specific policies such as the ones related to the use of masks. This is especially significant if one considers that the curtailing of civil rights in Italy has been much more extreme and closer to what one might be observe in China than in the U.S. This cannot be explained away by the gravity with which the pandemic hit China and Italy at the beginning of its global trajectory, because the U.S. pandemic ended up being one of the deadliest ones. In that context, it can be argued that similar to China, the Italian regulatory approach treated the pandemic as a more extreme type of emergency than the U.S. did, while leaving more space for civil contestation, if not the democratic process. That would potentially dismiss any talk of this state of extreme emergency being a state of exception.

A final argument from an Agambenian analysis according to which the Italian approach of invoking the state of exception would rely on the above-mentioned self-delegation of government power. Although in its form this resembles the form of exceptionality that Schmitt considers, the question to what extent and in what way will the limitations of rights that have occurred through this self-delegation of power become a valid legal precedent is fully open. It can be expected that it will be probed in the near future-and whatever the conclusion of that process, the sheer fact that these practices do not constitute a precedent automatically should help dismiss any Agambenian "extreme" views and lead us to a more moderate-and appropriate-understanding of the limitation of rights in tackling Covid-19.

Can we argue that the DPCMs indicate precisely what appears to be the fundamental paradox of current liberal democracies, that is, that a good emergency policy is one that renounces politics itself? If this were so, would we face a case of state of exception à la Schmitt or à la Agamben? Or would we find ourselves in the condition of a state of siege?

As far as the latter concept is concerned, Schmitt considers the 19th century evolution of dictatorship into a "state of siege" (Belagerungszustand), where civil and judicial powers are managed by the military. ${ }^{30}$ Certainly, it might appear that, in Italy, the nomination of General Figliuolo as Emergency Commissioner of Covid-19 by the new Prime Minister Mario Draghi points into such direction. Yet, cooperation of military forces with civilians during emergency crises are quite common and widespread in fully working liberal democratic countries. Arguably, military involvements into civil tasks cannot be equated without qualification to qualify a state of siege; the latter, for Schmitt, includes at the least the application of martial law.

Once dismissed the view that the category of the state of siege is a valid conceptual tool for the current democratic crisis, we consider more extensively to what extent a politics of emergency can lead to extra legem hegemonic powers (a state of exception proper) or, alternatively, whether current use of emergency powers fall within Schmittian Constitutional Emergency Law (Staatsnotrecht).

\footnotetext{
${ }^{30}$ SCHMITT, supra note 2 ("Finally, in a state of siege, all the legal functions of civilian authorities, in so far as they concerned maintaining internal order and the police force, were passed on to the commander, who exercised them as part of his personal responsibility.").
} 
The conclusion that is drawn is that the coronavirus pandemic does not raise foundational questions on power/constitutional restructuring. ${ }^{31}$ Accordingly, it has rejected the idea that the Covid-19 crisis bears a paradigmatic symbolic value for understanding the arguably legitimate —or illegitimate-exercise of power in contemporary liberal politics.

\section{E. On the Legitimacy of Use of Emergency Acts: The Italian Case}

Governments' reactions to the Covid-19 pandemic have mobilized several urgency measures raising issues of constitutional legitimacy. To be sure, current constitutional trends in the democratic life of states testify to a general reduction of the representative capacities of national parliamentary assemblies as well as of their chance to bring about "the most reasonable" outcome through public debates. Indeed, alternative measures have been already adopted independently from the consideration of current Covid-19 threats. Delegations, law decrees, stability pacts limiting parliamentary budgetary expenditure based on financial parameters, as well as international agreements and states obligations of compliance limiting the autonomy of parliamentary actions have already affected the democratic life of the states.

In addition, now, severe reductions in parliamentary participation have undercut the ability to participate and engage in public debate among MPs. This has also contributed substantially to diminish the deliberative democratic ability of the parliaments in favor of the executives. ${ }^{32}$

No wonder then that the Italian Government has also followed the same trend by adopting Decrees. But why not adopt the formula of Law Decrees and choose, instead, the more torturous and contestable route of the DPCM, namely, the Decrees of the President of the Council of Ministers? The former, in fact, would have preserved, on the basis of the motivation of "necessity and urgency," at least a minimal standard of consultation necessary for the parliamentary transfer of the decrees into law. The latter, unfortunately, paves the way to a symbolic disavowal of the parliamentary political legitimization of governmental acts. This is even more significant due to the limitation of fundamental freedoms that these measures accomplish-particularly that of movement-but with a significant effect also on other important liberties, such as freedom of religion, of assembly, and others.

It is certainly the case that Article 16 of the Italian Constitution allows for the limitation of the free circulation of its citizens for reasons of security and health. Yet, the political decision of whether something presents itself as a relevant case can hardly be defined above the will of the Parliament through Decrees. What seems truly problematic here is the legitimacy of the

\footnotetext{
${ }^{31}$ See id. (Contrasting the constitutional use of emergency laws with any attempt to subvert the constitution by coup d'état, Schmitt writes: "It is conceivable that, in an extreme situation, a constitutional emergency law would be enforced autonomously, alongside the authority of Article 48; and, in the specific circumstances, the government of the Reich on its own, and not its president, would appear to support this emergency law [Notrecht]. In fact if, for example, extensive parts of the Reich were occupied by the enemy or there were a coup d'état, it is conceivable to exercise this legal authority even against a president of the Reich in order to salvage the constitution-maybe because the president refuses to declare state of exception ... Article $48, \$ 2$, in contrast, regulates the state of emergency as a constitutional legal instrument [emphasis added]. As a result, any confusion with constitutional emergency law becomes impossible. The next question about constitutional emergency law-whether it is possible to eliminate the constitution itself and to introduce another constitution, in other words to have a kind of right to a coup d'état — need not be discussed here .... Such a right certainly does not follow from Article 48.")

${ }^{32}$ For Weiler comments on the current political scenario, see J.J. Weiler, Covid, Europe, and Democratic Self-Asphyxiation, in Democracy in Times of Pandemic: Different Futures Imagined 152 (M. Poiares-Maduro and P.W. Kahn eds., 2020) ("What is happening in Europe is not a coup d'état. It is a long process of widespread degradation of democracy in many of our Member States and of collective democratic self-asphyxiation ...." See also, A. Malaschini, Sulle concrete misure adottate dal Parlamento in occasione dell'emergenza covid-19, in FORUM DI QUADERNI CosTITUZIONALI 269 (2020), www. forumcostituzionale.it.
} 
procedure followed by the government in assuming emergency powers through the adoption of a law Decree followed by a Decree of the Prime Minister (DPCM).

Who has allowed the Prime Minister to adopt emergency measures to contrast the Covid-19 pandemic? No one. Indeed, the first Law Decree dated Feb. 23, 2020, was followed by a series of DPCMs through which the Prime Minister gave actualization until enactment of a further Law Decree dated March 2, 2020, also followed by a series of DPCMs. The Parliament has not been empowered in this process, as it should have, in order to transform a provisional measure into proper law within sixty days. ${ }^{33}$ So, even if it can be admitted that the actions of the Government were justifiable in light of constitutional articles and judicial standards like that of proportionality or legitimate aim-parameters that, for the sake of a legitimacy assessment on human rights infringements, one can usefully borrow from the ECtHR-what remains contestable is the adoption, in the first place, of the "decree strategy" in the absence of parliamentary debate in view of the shift to an emergency management of the virus crisis by the government.

With the starting point illegitimate, it is hard to admit that the overall action of the government can be considered legitimate in the outcomes only, with the exception of the procedures. Indeed, only forms of paternalism in the conception of government power could allow for such appreciative acceptance of the government's actions. Yet, within the framework of Constitutional Emergency Law (Staatsnotrecht) what is procedurally illegitimate can remain nevertheless constitutionally justified.

\section{F. Conclusion}

If it is not a state of exception, and if it is not a stage of siege, then what sort of emergency is the war against Covid-19? What sense can we make of this cognitive metaphor, if any? The use of metaphorical frames is never neutral as Lakoff informs us. ${ }^{34}$ Thus, evidently, Trump's expression, "the Chinese virus," is not neutral when he externalizes the responsibilities for the current American public health crisis. ${ }^{35}$

There is in fact no war against Covid-19, nor should there be one. Rather, the pandemic Covid19 calls for a cooperative emergency reaction for the containment of the virus and its effects. This prompts a sort of collective responsibility rather than war. There is not really an opposing front to blame except the virus itself. Therefore, strategies aimed at externalizing responsibilities or empty parliamentary participation should be avoided.

As shown, the emergency use of the power exhibited by the DPCMs arises within an already established framework of constitutional justification. The limitations of freedom do not hint currently to a foundational self-constituting act of the political power. The current crisis of the Italian government testifies of a "business as usual" process led by the President of the Republic in conferring a mandate for a renewed consensus. There is no overstepping of the border between the law and the extra legem (exception). It is therefore misleading to speak of a state of exception in

\footnotetext{
${ }^{33}$ The most relevant acts of this initial phase are: Decreto Presidente del Consiglio dei Ministri 23 febbraio 2020, n. 6 (It.); Decreto Presidente del Consiglio dei Ministri. 25 febbraio 2020 (It.); Decreto Presidente del Consiglio dei Ministri 1 marzo 2020 (It.); Decreto legge 2 marzo 2020, n. 9 (It.); Decreto Presidente del Consiglio dei Ministri 4 marzo 2020 (It.); Decreto legge 8 marzo 2020, n. 11 (It.).

${ }^{34}$ G. Lakoff \& M. Johnson, Metaphors We Live By (1980); G. LAKoff, Women, Fire and Dangerous Things (1987).

${ }^{35} \mathrm{~A}$ recent debate in this respect appeared on Italian magazines. See, for instance, D. Cassandro, Siamo in guerra! Il coronavirus e le sue metafore, INTERNAZIONALE (Mar. 22, 2020), https://www.internazionale.it/opinione/daniele-cassandro/2020/ 03/22/coronavirus-metafore-guerra; A. Testa, Smettiamo di dire che è una guerra, InTERnAZIONALE (Mar. 30, 2020), https:// www.internazionale.it/opinione/annamaria-testa/2020/03/30/metafora-guerra-coronavirus; F. Battistelli, Coronavirus: metafore di guerra e confusione di concetti, MicromeGA (Mar. 24, 2020), http://temi.repubblica.it/micromega-online/ coronavirus-metafore-di-guerra-e-confusione-di-concetti/.
} 
this case. Yet, as illustrated, and particularly for the Italian case, the emergency measures adopted by the current government reveal procedural difficulties particularly with regard to the weak, if not at times absent, coordination between the Government cabinet and the Parliament as well as its regional counterparts. But these actions, in so far as they do not challenge the grounding bases of the liberal democratic institutions, could be tolerable—justifiable—ad hoc decisions.

Cite this article: Corradetti C, Pollicino O (2021). The "War" Against Covid-19: State of Exception, State of Siege, or (Constitutional) Emergency Powers?: The Italian Case in Comparative Perspective. German Law Journal 22, $1060-1071$. https://doi.org/10.1017/glj.2021.48 